\title{
Australian Journal of Crop Science \\ Yield and physiological quality of seeds of different bean genotypes produced in the off-season period in subtropical climate
}

\author{
Felipe Koch ${ }^{1}$, Geison Rodrigo Aisenberg ${ }^{1}$, Vinícius Jardel Szareski ${ }^{1}$, Gustavo Henrique Demari ${ }^{1}$, Ivan \\ Ricardo Carvalho ${ }^{1}$, João Roberto Pimentel ${ }^{1}$, Cristian Troyjack ${ }^{1}$, Maicon Nardino ${ }^{1}$, Francine Lautenchleger ${ }^{2}$, \\ Velci Queiróz de Souza ${ }^{3}$, Braulio Otomar Caron ${ }^{4}$, Francisco Amaral Villela ${ }^{1}$, Tiago Zanatta Aumonde ${ }^{1}$, \\ Tiago Pedó ${ }^{1}$
}

\author{
${ }^{1}$ Universidade Federal de Pelotas, CEP 96010-610, Capão do Leão, RS, Brazil \\ ${ }^{2}$ Universidade Tecnológica Federal do Paraná Campus Dois Vizinhos, PR, Brazil \\ ${ }^{3}$ Universidade Federal do Pampa, Dom Pedrito, RS, Brazil \\ ${ }^{4}$ Universidade Federal de Santa Maria Campus de Frederico Westphalen, RS, Brazil
}

*Corresponding authors: viniciusszareski@gmail.com

\begin{abstract}
The objective of this work was to evaluate the yield and physiological quality of seeds of different bean genotypes produced in the off-season period in the subtropical region of Rio Grande do Sul state. The work was divided in two experiments. The first one evaluated the number of pods per plant, number of seeds per plant, number of seeds per pod, thousand seed weight and seed yield per plant of five bean genotypes (IPR Tuiuiú, BRS Embaixador, Guabiju, Carioquinha and Mouro ), during 2013 and 2014 offseason periods. In the second study, the physiological quality of the seeds such as germination, first germination count, shoot and root dry matter were measured under different osmotic potentials $(0.0,-0.09,-0.18$, and $-0,27 \mathrm{MPa})$ at temperatures of 25 and $35^{\circ} \mathrm{C}$. Moreover, the isoenzymatic expression of the seedlings at the temperatures 25 and $35^{\circ} \mathrm{C}$, of the seeds from the $2013 \mathrm{crop}$ was evaluated. The results showed that IPR Tuiuiú and Carioca genotypes have superiority in yield components, whereas the BRS Embaixador showed the highest Thousand seed weight. The physiological quality of the seeds was reduced in the lower osmotic potentials at both temperatures. The expression and intensity of isoenzyme peroxidase bands were higher in potencies of -0.09 and $-0.18 \mathrm{MPa}$ for all genotypes at both temperatures.
\end{abstract}

Keywords: Phaseolus vulgaris, agricultural crops, vigor, isoenzymes.

Abbreviations: $P E G_{-}$Poly Ethylene Glycol, $G_{-}$germination, $P_{C} G_{-}$first germination count, $W_{P_{\_}}$dry mass of aerial part, $W_{R_{-}}$root dry mass, Ve_BRS Embaixador cultivar, Tu_IPR Tuiuiú, Pe_Guabiju, Ca_Carioquinha, Mo_Mouro, NPP_Means of number of pods per plant, NSP_number of seeds per plant, NS/P_number of seeds per pod, TGW_thousand grain weight, SY_seed yield per plant. of five common bean genotypes in the off-season period of the 2013 and 2014 agricultural years.

\section{Introduction}

The common bean (Phaseolus vulgaris L.) is a major source of protein for most of the human population, having economic and social importance. Common bean production in Brazil is approximately 3.3 million tonnes, reaching an average yield of approximately $1 \mathrm{t} \mathrm{ha}^{-1}$. In the state of Rio Grande do Sul, the production is approximately 974,000 tons with an average yield of about $1.7 \mathrm{t} \mathrm{ha}^{-1}$ (Conab, 2017).

In Brazil, common bean is grown in three agricultural seasons and subjected to different environmental conditions (Melo et al., 2007). The yield of agricultural crops is likely to decrease because of adversities in temperature, luminosity, and excess or lack of rainfall, which are limiting factors for grain production (Fioreze et al., 2011). In Rio Grande do Sul, the occurrence of water deficit is common during the common bean growing period, in which the yield reductions for this crop are expected (Matzenauer et al., 2004).
The germination conditions of seeds in the soil such as water stress are sometimes adverse (Szareski et al., 2016). The reduction of seeds germination under water stress is attributed to the reduction of the enzymatic activities. On the other hand, the seeds (especially the driest ones) can absorb water quickly under full availability of water in the soil, causing ruptures in their tissues, with consequent damages to the germination. Beans are very sensitive to the lack of water after after sowing (Neto et al., 2006; Marrou et al., 2006). Values below $(-0.35 \mathrm{MPa})$ can dramatically reduce seed germination and elongation (Durval and Fancelli, 2000). However, in a laboratory experiment germination was occurred even after six days under water deficient condition at $-1.5 \mathrm{MPa}$ in seeds of bean cultivars (Lemos and Machado Neto, 1999; Machado Neto et al., 2003).

Unfavorable environmental conditions, such as high temperatures and water stress cause effects on cultivated 
plants. Characterization of common bean genotypes subjected to these stressful environments can assist making decisions about the use of these genotypes in adverse conditions, maximizing yield and seed production with high quality.

The water absorption by seed is an essential physicalchemical process to increase the metabolic activity after physiological maturity. Water is capable of dissolving large amounts of compounds with high chemical potential and plays a key role in the germination process by allowing tissue rehydration, intensification of respiratory activity and other metabolic processes seeking the synthesis of new compounds, hydrolysis, and translocation of assimilates to the embryo (Peske et al., 2012).

The seed germination process can be compromised by negative water potential that influences water absorption by seeds (Lopes and Macedo, 2008; Peske et al., 2012) and in the expression of isoenzymes (Devi et al., 2007; Troyjack et al., 2017). The expression of seed vigor, initial plant growth, and isozymes expression may vary depending on the genotype and temperature (Facin et al., 2014; Dubal et al., 2016).

This study aimed to evaluate the yield and seed physiological quality of different common bean genotypes grown in the off-season period in Rio Grande do Sul.

\section{Results and Discussion}

\section{Yield of genotypes grown during the off-season period}

The NPP was higher in Carioca genotype during the 2013 offseason period, while there were no differences between plants of the Carioca and IPR Tuiuiú genotypes during the 2014 off-season period (Table 2). In both off-season periods, Guabiju genotype had the lowest pod yield compared to the other genotypes. Pod production is attributed to the availability and incident of solar radiation on plants (Table 1), photoperiod and temperature, which influence the number and the development rate of the reproductive primordia (Jiang et al., 2011).

The traits NSP and NS/P showed different behavior among genotypes in both agricultural years for the off-season periods (Table 2). In the 2013 off-season period, Carioca genotype produced more number of seeds compared to the other genotypes. Meanwhile, in the 2014 off-season period, the greatest NSP and NS/P were obtained by IPR Tuiuiú genotype. Environmental conditions are important factors for the crop yield performance (Table 1), where different environmental conditions among years may interfere on the number of grains per area (Sousa and Lima, 2010).

The TGW was greater in the BRS Embaixador genotype in the off-season period in both agricultural years (Table 2). The lowest TGW among all genotypes was obtained in plants of the Carioca genotype grown in both off-season periods. These lower values are phenotypic characteristics and related to high seed production of this genotype, as seen by the largest NSP (Table 2).

The mass accumulation in seeds is related to the production of assimilates in the leaves and allocated in seeds (Lopes and Lima, 2015). Moreover, it is determined by genotype characteristics and environmental conditions of solar radiation and temperature (Mittler and Blumwald, 2010).
The seed yield per plant (SY) in 2013 off-season period was higher for the genotypes BRS Embaixador, IPR Tuiuiú, and Carioca (Table 2). By analyzing the 2014 off-season period, the SY per plant was greater for IPR Tuiuiú genotype. In the same agricultural year, the lower SY of BRS Embaixador genotype can be attributed to the decrease in the NPP and NSP combined with lower adaptation in the off-season cropping. Moreover, the decrease of temperature and solar radiation over time (Table 1 ) influenced the growth and seed filling (Cruz et al., 2010).

Common bean is sensitive to environmental changes during flowering (Didon and Silva, 2004) and may cause flower abortion and drop of pods (Silva et al., 2006). According to Stülp et al. (2009) and Alcantara et al. (2011), sowing outside the appropriate time can cause a reduction of $50 \%$ in SY of soybeans and change the chemical composition of the produced grains.

\section{Quality of seeds under water restriction}

From the analysis of the results, there was no significant interaction between water restriction and analyzed genotypes (Fig 1). The seed and seedling performance of the five common bean genotypes on the different water restrictions was simulated by polyethylene glycol (PEG).

Seed germination at $25^{\circ} \mathrm{C}$ was reduced in genotypes Guabiju, Mouro, and BRS Embaixador, respectively, by water restriction (Fig 1a). The genotypes IPR Tuiuiú and Carioquinha presented similar trend and the highest germination values observed under better water potential, when compared to other genotypes. Meanwhile, in temperature of $35^{\circ} \mathrm{C}$ (Fig $1 \mathrm{~b}$ ), the same results like those at $25^{\circ} \mathrm{C}$ were observed (Fig 1a). However, lower values were obtained by the Mouro genotype at $35^{\circ} \mathrm{C}$.

Studying the seed germination and vigor of maize hybrids under water deficit, Kappes et al. (2010) found that the germination is reduced by lowering the osmotic potential. Similar results were found by Carvalho et al. (2013), where the seed performance of common bean evaluated under the action of different osmotic potentials simulated by polyethylene glycol.

The FGC of seeds of all genotypes showed a quadratic trend with high coefficients of determination (Fig 1c, 1d). There was a reduction in germination by decreasing the osmotic potential of the solution to all seeds of genotypes at $25 \circ$. More drastic results were observed in Guabiju, while the best results were obtained by the IPR Tuiuiú and Carioquinha (Fig 1C). Meanwhile, the highest values of FGC were found in IPR Tuiuiú and Carioquinha at $35^{\circ} \mathrm{C}$ (Fig 1d). However, the Mouro genotype presented the lowest values of FGC with the reduction of osmotic potential at this temperature (Fig 1d).

These results are probably due to the occurrence of low water availability for seed germination process, causing a negative influence on the process of respiration, mobilization of reserves, hydrolytic enzymatic activity and in the activation of different physiological processes related to germination and vigor (Peske et al ., 2012).

The APDM presented tendency with high coefficient of determination $\left(R^{2} \geq 0.88\right)$ to decrease with the osmotic potential at $25^{\circ} \mathrm{C}$ (Fig 1e). At this temperature, more severe results were imposed by the osmotic potential on growth attributes of BRS Embaixador, Mouro, Carioca, IPR Tuiuiú, 
Table 1. Temperature ( $T$ ), relative humidity $(\mathrm{RH})$, and solar radiation (SR) incidents in Ametista do Sul - RS during the eoff-season periods of 2013 and 2014 agricultural years. Source: Federal University of Santa Maria (UFSM) - Campus of Frederico Westphalen RS in 2014.

\begin{tabular}{llllll}
\hline Months & $\mathrm{T}(\mathrm{o})$ & & $\mathrm{C})$ & $\mathrm{RH}(\%)$ & $\mathrm{SR}$ \\
\cline { 2 - 6 } & Maximum & Minimum & Maximum & Minimum & $\left(\mathrm{kJ} \mathrm{m}^{-2}\right)$ \\
\hline January & 2013 & & & & \\
February & 23.91 & 22.3 & 72.37 & 65.11 & $1,100.2$ \\
March & 23.54 & 22.05 & 80.13 & 73.71 & 913.0 \\
April & 20.75 & 19.51 & 82.23 & 76.96 & 684.0 \\
\hline & 19.82 & 18.22 & 77.08 & 69.75 & 944.4 \\
\hline January & 2014 & & & & \\
February & 25.01 & 23.51 & 80.52 & 73.42 & $1,111.8$ \\
March & 25.46 & 23.82 & 73.20 & 65.33 & $1,038.75$ \\
April & 22.02 & 20.64 & 80.54 & 74.22 & 806.24 \\
\hline
\end{tabular}
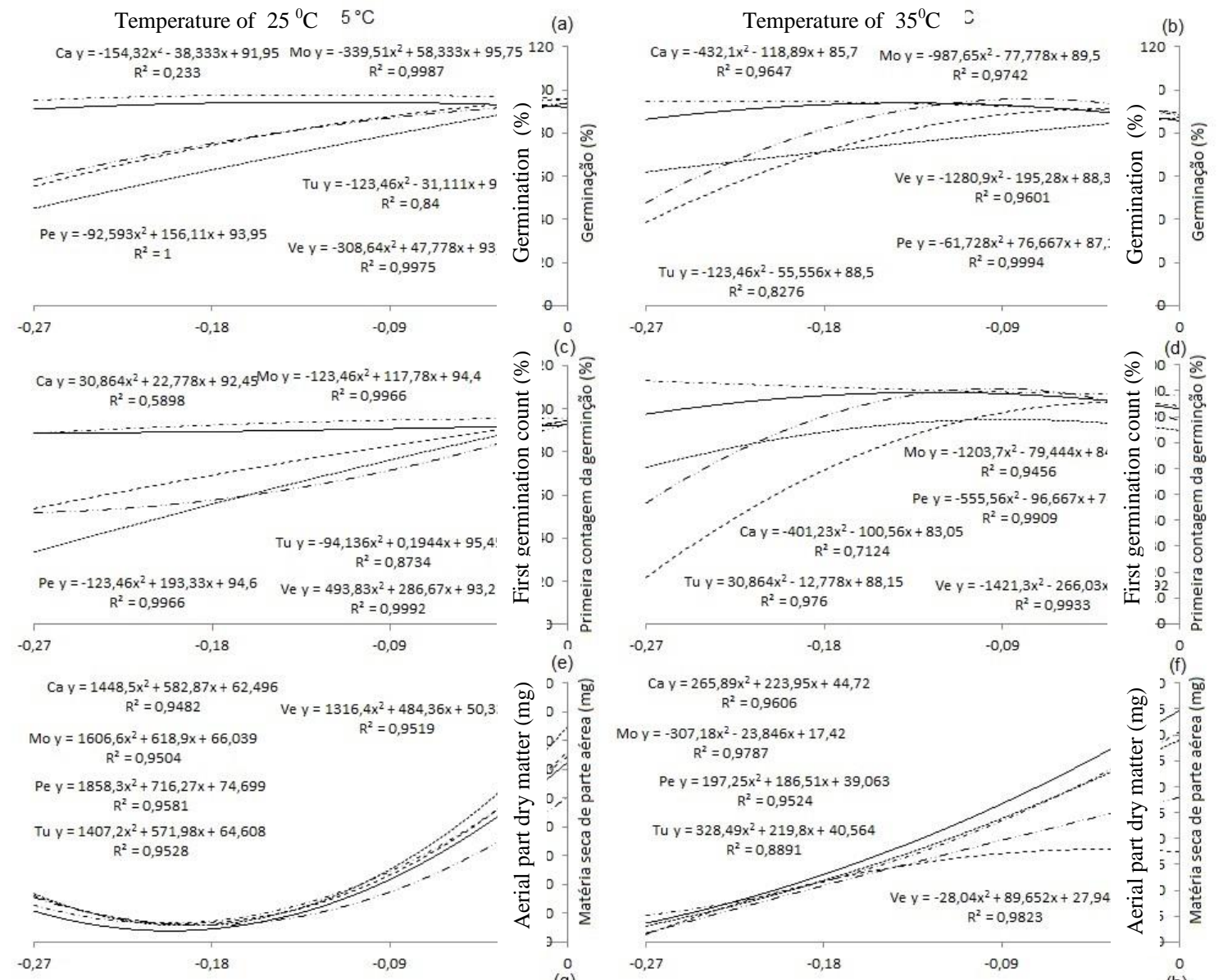

Mo $y=-307,18 x^{2}-23,846 x+17,42$
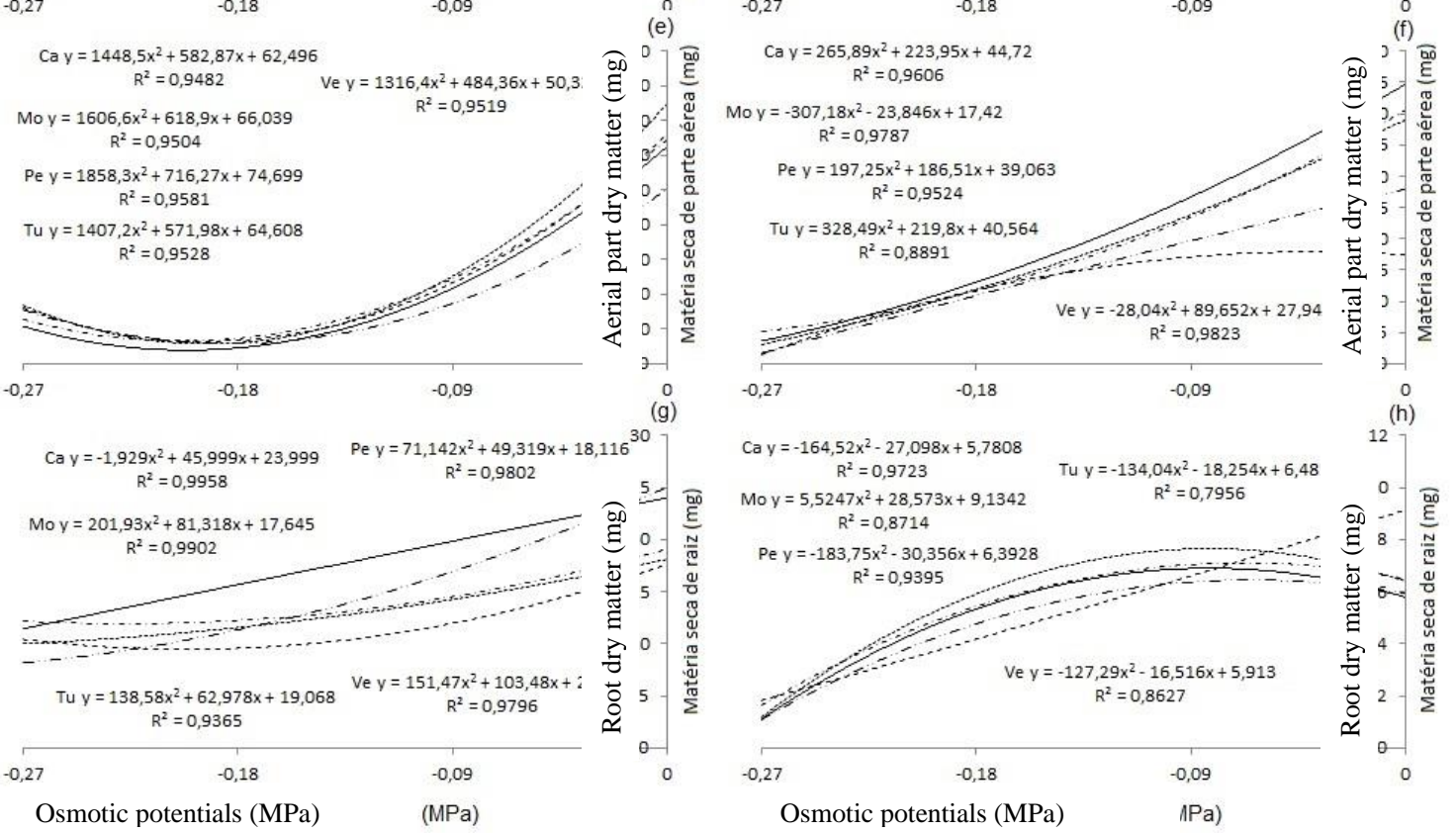

Fig 1. Germination $(a, b)$, first germination count $(c, d)$, aerial part dry matter $(e, f)$; and root dry matter $(g, h)$ of seeds and seedlings of common bean genotypes under different osmotic potentials in the temperatures of $25^{\circ} \mathrm{C}$ and $35^{\circ} \mathrm{C}$. 
Table 2. Means of number of pods per plant (NPP), number of seeds per plant (NSP), number of seeds per pod (NS/P), thousand grain weight (TGW), and seed yield per plant (SY) of five common bean genotypes in the off-season period of the 2013 and 2014 agricultural years.

\begin{tabular}{|c|c|c|c|c|c|}
\hline Genotypes & NPP & NSP & $\mathrm{NS} / \mathrm{P}$ & TGW(g) & $\mathrm{SY}(\mathrm{g})$ \\
\hline \multicolumn{6}{|l|}{2013} \\
\hline Embaixador & $10.6 c^{1}$ & $38.2 d$ & $3.7 c$ & $450.9 a$ & $17.2 a$ \\
\hline Tuiuiú & $12.8 b$ & $55.1 b$ & $4.8 \mathrm{a}$ & $293.9 c$ & $17.5 a$ \\
\hline Guabiju & $11.6 \mathrm{bc}$ & $38.7 d$ & $3.3 d$ & $334.0 \mathrm{~b}$ & $12.9 \mathrm{c}$ \\
\hline Mouro & $11.2 \mathrm{c}$ & $46.9 c$ & $4.2 b$ & $339.7 b$ & $14.3 \mathrm{~b}$ \\
\hline Carioquinha & $16.9 a$ & $61.2 \mathrm{a}$ & $3.9 c$ & $259.4 d$ & $18.2 \mathrm{a}$ \\
\hline CV (\%) & 19.1 & 9.7 & 14.8 & 3.0 & 16.0 \\
\hline \multicolumn{6}{|l|}{2014} \\
\hline Embaixador & $8.1 d$ & $25.9 d$ & $3.3 c$ & $391.3 a$ & $10.2 d$ \\
\hline Tuiuiú & $19.4 a$ & $106.3 a$ & $5.4 a$ & 187.1e & $19.6 a$ \\
\hline Guabiju & $12.6 c$ & $41.5 c$ & $3.3 c$ & $297.5 c$ & $12.8 \mathrm{c}$ \\
\hline Mouro & $13.4 \mathrm{c}$ & $44.8 c$ & $3.4 \mathrm{c}$ & $374.6 b$ & $16.9 \mathrm{~b}$ \\
\hline Carioquinha & $18.7 a$ & $79.9 b$ & $4.3 b$ & 208.9d & $16.7 \mathrm{~b}$ \\
\hline CV (\%) & 9.2 & 13.1 & 9.7 & 2.9 & 13.9 \\
\hline
\end{tabular}

${ }^{1}$ Means followed by the same letter do not differ among themselves by Tukey test $(p<0.05)$.

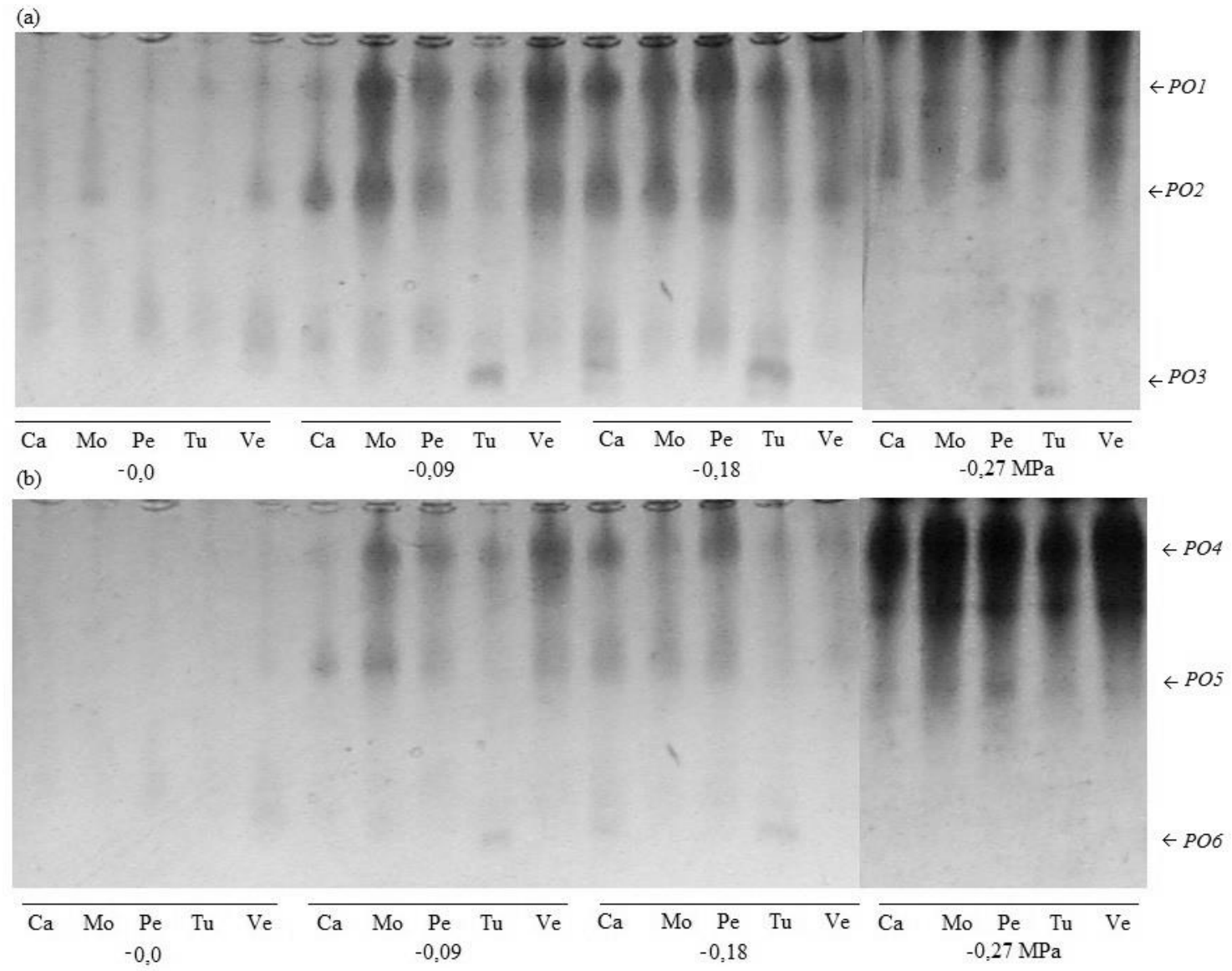

Fig 2. Expression of the peroxidase isoenzyme in seedlings of different common bean genotypes (BRS Embaixador (Ve), IPR Tuiuiú (Tu), Guabiju (Pe), Carioquinha (Ca), and Mouro (Mo) submitted to different water potentials with temperatures of $25^{\circ} \mathrm{C}(\mathrm{a})$ and $35^{\circ} \mathrm{C}(\mathrm{b})$, where $\mathrm{PO} 1, \mathrm{PO} 2, \mathrm{PO} 3$ indicate the band expression region of the peroxidase enzyme at temperature $25^{\circ} \mathrm{C}$. The $\mathrm{PO} 4, \mathrm{PO} 5$ and PO6 indicate band expression at temperature 35으. 
and Guabiju, respectively (Fig1e). Meanwhile, the lowest growth was obtained by genotypes Mouro, BRS Embaixador, Guabiju, IPR Tuiuiú and Carioca at $35^{\circ} \mathrm{C}$ (Fig 1f). The RDM of seedlings of five genotypes subjected to water restriction and exposed to temperatures of $25^{\circ} \mathrm{C}$ and $35^{\circ} \mathrm{C}$ presented reduction in the osmotic potential of $-0.27 \mathrm{MPa}$ (Fig $1 \mathrm{~g}$ and 1h). The lower dry matter values of seedlings in the lower osmotic potentials are explained by lower utilization of assimilates stored in the endosperm and by the lack of available water for growth (Peske et al., 2012).

\section{Isoenzymatic expression}

The peroxidase isoenzyme demonstrated higher expression in the number and intensity of bands, while the osmotic potential was reduced at temperatures of $25^{\circ} \mathrm{C}$ and $35^{\circ} \mathrm{C}$ (Fig 2a; 2b). There was the expression of three alleles for both seedlings produced in $25^{\circ} \mathrm{C}$ and $35^{\circ} \mathrm{C}$, with greater intensity in the potentials of -0.09 and $-0.18 \mathrm{MPa}$. Seedlings of IPR Tuiuiú genotype presented higher intensity of bands for both temperatures $\left(25^{\circ} \mathrm{C}\right.$ and $\left.35^{\circ} \mathrm{C}\right)$. The increased expression such as number and intensity of peroxidase under more negative water potentials may somehow explain the reduction in germination of common bean seeds (Fig $1 \mathrm{a}, 1 \mathrm{~b}$ ). This indicates that these potentials cause a stress condition by exercising negative influence in the seeds during germination process. The peroxidase isoenzyme is related with defense mechanisms regarding several abiotic stresses (Lee et al., 2001; Hsu and Kao, 2003; Aisenberg et al., 2016) and constitute antioxidative protection (Rossi et al., 1997) on the exposed seedlings against adverse environmental conditions. The reduction in the activity of this isoenzyme may affect the seed performance (Henning et al., 2010; Pedó et al., 2016), as observed with reduced seed quality (Fig 1).

\section{Materials and Methods}

The experiment was carried out in the city of Ametista do Sul, RS. Southern Brazil located at latitude of $27^{\circ} 20^{\prime} 20.98^{\prime \prime S}$ and longitude of $53^{\circ} 11^{\prime} 5.32^{\prime \prime} \mathrm{W}$, and altitude of $322 \mathrm{~m}$. According to Köppen climate classification, the climate of region is $\mathrm{Cfa}$, ie, humid subtropical with an average annual temperature of $19.1^{\circ} \mathrm{C}$, varying with maximum of $38^{\circ} \mathrm{C}$ and minimum of $0^{\circ} \mathrm{C}$ (Alvares et al., 2013). The soil of the experimental area is classified as Oxisol distrofic typical, clayey, deep and well drained. For sowing the adjustment of the fertilization was carried out according to the fertilization and liming manual (Embrapa, 2006; CQFS RS/SC, 2004). Soil chemical analysis showed $\mathrm{pH}$ of $6.3, \mathrm{CEC}$ at $\mathrm{pH} 7$ of $21.1 \mathrm{cmol}_{\mathrm{c}}$ $\mathrm{dm}^{-3}$, base saturation of $83 \%$, organic material of $2.4 \%$, texture at 3 , clay at $31 \%$, phosphorus of $50.3 \mathrm{mg} \mathrm{dm}^{-3}$, potassium of $190 \mathrm{mg} \mathrm{dm}{ }^{-3}$, calcium of $13.6 \mathrm{cmol}_{\mathrm{c}} \mathrm{dm}^{-3}$, magnesium of $3.5 \mathrm{cmol}_{\mathrm{c}} \mathrm{dm}^{-3}$, and sodium of $13 \mathrm{mg} \mathrm{dm}^{-3}$. Data of temperature, relative humidity, and solar radiation were obtained from the bulletin of the Agrometeorological Station of the Federal University of Santa Maria, campus of Frederico Westphalen - RS (Table 1). The research was divided into two phases, as follows:

\section{Yield assessment of genotypes grown during the off-season period}

The experimental design was randomized blocks with five replications per treatment of 25 plants. The treatments consisted of five genotypes assessed for yield performance during two agricultural off-season periods (2013 and 2014).

The seeds were sown in early January during the off-season period during the 2013 and 2014 agricultural years. Seeds of five common bean genotypes were used: BRS Embaixador (large dark red commercial group), IPR Tuiuiú and Guabiju (black commercial group), Carioquinha (carioca commercial group), and Mouro (brindle trade group). The seed harvest was carried out when they reached humidity of $16 \%$. Plants were harvested and processed manually with removal of inert material and visually damaged seeds. The post-harvest storage of seeds of genotypes occurred in a cold and dry chamber $\left(10^{\circ} \mathrm{C} / 45 \%\right)$ during the period of performing experiments.

The following variables were used to assess the yield attributes:

Number of pods (NPP) per plant and number of seeds per plant (NSP) were obtained by direct counting of the number of pods and seeds per plant.

Number of seeds per pod (NS/P) was determined by dividing the total number of seeds per plant by the total number of pods per plant;

Thousand grain weight (TGW) was obtained by counting eight replications of 1000 seeds and expressed in grams (Brazil, 2009).

Seed yield per plant (SY) was determined from the seed weight, expressed in grams per plant.

\section{Evaluation of the physiological quality of seeds}

For evaluation of the physiological and isoenzymatic quality, only the seeds produced in the 2013 crop were used. The seeds were subjected to the same post-harvest procedure used in "phase a" of this research. In order to assess water stress tolerance, five genotypes were used (IPR Tuiuiú, BRS Embaixador, Guabiju, Carioquinha, and Mouro) and four osmotic potentials $(0.0,-0.09,-0.18$, and $-0.27 \mathrm{MPa})$ at two temperatures $\left(25^{\circ} \mathrm{C}\right.$ and $\left.35^{\circ} \mathrm{C}\right)$ were applied during seed germination.

Water restriction was established from preliminary trials through solutions composed by distilled water and different concentrations of polyethylene glycol (PEG-6000), using the ratio between mass and volume $(\mathrm{m} / \mathrm{v})$. The following tests were performed in order to evaluate the influence of water deficit on the seed physiological performance and isozyme expression in common bean seedlings:

Germination test (G) was performed with eight replications of 50 seeds disposed to germinate in rolls formed by three germitest paper sheets, moisturized with distilled water in the amount of 2.5 times the dry weight of the dry paper. The rolls were transferred to the B.O.D. germination chamber at $25^{\circ} \mathrm{C}$ and $35^{\circ} \mathrm{C}$ and photoperiod of 12 hours. The assessments were performed at nine days after sowing (DAS) and the results expressed as a percentage of normal seedlings, according to the Rules of Seed Analysis (Brazil, 2009).

First germination count (FGC) was performed together with the germination test at five DAS, according to the Rules of Seed Analysis (Brazil, 2009). The results were expressed as a percentage of normal seedlings.

Aerial part dry matter (APDM) and root dry matter of seedlings (RDM) were obtained by the measurement of four samples of 10 seedlings at the end of the germination test. The seedlings were placed in brown paper envelopes and 
dried in forced ventilation oven at a temperature of $70^{\circ} \mathrm{C}$ for 72 hours. The results were expressed in milligrams per organ $\left(\right.$ mg organ $\left.^{-1}\right)$.

\section{Isoenzymatic expression}

Isoenzyme expression: the plant material used for the determination of isoenzyme expression was obtained by collecting 10 seedling of the germination test at nine DAS. The expression of peroxidase isoenzyme was determined by vertical electrophoresis system in polyacrylamide gel. The electrophoresis was performed in $7 \%$ polyacrylamide gels, applying $20 \mu \mathrm{L}$ of each sample. In this study, the coloring systems described by Scandálios (1969) and Alfenas (1998) were used. Furthermore, the interpretation of the results was through visual inspection of the gels, with the presence or absence of expression and intensity of band expression.

\section{Statistical procedures}

The data were subjected to the Shapiro-Wilk test for normality (1965) and variation of variances homogeneity by Hartley (Ramalho et al., 2012). Subsequently, they were subjected to analysis of variance. If the data was significant by $\mathrm{F}$ test, the means were compared by Tukey test at $5 \%$ probability $(p<0.05)$. While the data related to the germination and initial growth were subjected to analysis of variance and if significant at $5 \%$, they were adjusted by orthogonal polynomials.

\section{Conclusion}

The IPR Tuiuiú and Carioca genotypes showed superiority in yield components, whereas the BRS Embaixador showed the highest thousand seed weight. The physiological quality of the seeds was reduced in the lower osmotic potentials at both temperatures. The expression and intensity of isoenzyme peroxidase bands were higher in potencies of 0.09 and $-0.18 \mathrm{MPa}$ for all genotypes at both temperatures.

\section{Acknowledgements}

The authors wish to thank the National Council for Scientific and Technological Development (CNPq), and the Coordination for the Improvement of Higher Education Personnel (CAPES), for the support.

\section{References}

Aisenberg GR, Zimmer G, Koch F, Dellagostin SM, Szareski VJ, Carvalho IR, Nardino M, Souza VQ, Pedo T, Martinazzo EG, Villela FA, Aumonde TZ (2016) Biochemical performance, vigor and characteristics of initial growth of wheat plants under different sowing depths. Inter J Cur Research, 8(8): 36704 - 36709.

Alcantara HP, Rezende PM, Carvalho ER, Passos AMA, Botrel EP (2011) Consórcio sorgo-soja. XVI. Cortes, épocas de semeadura e cultivares de soja na produção de forragem. R Ciênc Agron. 42(1): 116-124.

Alvares CA, Stape JL, Sentelhas PC, Moraes G, Leonardo J, Sparovek G (2013) Köppen's climate classification map for Brazil. Meteorol Z. 22(6):711-728.
Brasil - Ministério da Agricultura e da Reforma Agrária. Regras para análise de sementes (2009) Secretaria de Defesa Agropecuária. Brasília: Mapa/ACS, 399p.

Carvalho TC, Silva SS DA, Silva RC DA, Panobianco ME, Mógor AF (2013) Influência de bioestimulantes na germinação e desenvolvimento de plântulas de Phaseolus vulgaris sob restrição hídrica. R Ciênc Agr Lisboa. 36(2): 199-205.

Conab - Acompanhamento da safra brasileira de grãos (2017) Safra 2016/17, Oitavo levantamento, maio. 2017. 144p.

CQFS Manual de adubação e calagem para os Estados do Rio Grande do Sul e Santa Catarina (2004) Sociedade Brasileira de Ciência do Solo. 10a. ed. 400 p.

Cruz TV, Peixoto CP, Martins MC (2010). Crescimento e produtividade de soja em diferentes épocas de semeadura no oeste da Bahia. Sci Agr. 11(1): 33-42.

Devi R, Munjral N, Gupta AK, Kaur N (2007) Cadmium induced changes in carbohydrate status and enzymes of carbohydrate metabolism, glycolysis and pentose phosphate pathway in pea. Environ Exp Bot. 61(2): 167174.

Didon AD, Silva, SC (2004) Elementos climáticos e produtividade do feijoeiro. Informe Agropecuário, 25(223): 13-19.

Dubal ITP, Troyjack C, Koch F, Aisenberg GR, Szareski VJ, Pimentel JR, Nardino M, Carvalho IR, Olivoto T, Souza VQ, Villela FA, Aumonde TZ, Pedó T (2016) Effect of temperature on bean seed germination: vigor and isozyme expression. Agric Sci Res J. 1(5): 0001- 0009.

Durval DN, Fancelli AL (2000) Produção de feijão. Guaíba: Agropecuária. 385p.

Embrapa - Empresa Brasileira de Pesquisa Agropecuária. Sistema Brasileiro de Classificação de Solos (2006). 2 ed. Rio de Janeiro: Embrapa-SPI. 412p.

Facin F, Pedó T, Koch F, Martinazzo EM, Villela FA, Aumonde TZ (2014) Vigor de sementes e crescimento inicial de plantas de feijãosob efeito de baixas temperaturas. Tecnol Ciên Agropec. 8(4): 35-40.

Fioreze SL, Pivetta LG, Fano A, Machado FR, Guimarães VF (2011) Comportamento de genótipos de soja submetidos a déficit hídrico intenso em casa de vegetação. Revista Ceres. 58(3): 342-349.

Henning FA, Mertz LM, Jacob Junior EA,Machado RD, Fiss G, Zimmer PD (2010) Composição química e mobilização de reservas em sementes de soja de alto e baixo vigor. Bragantia. 69(3): 727-734.

Kappes C, Andrade JAC, Haga KI,Ferreira JP,Arf MV (2010) Germinação, vigor de sementes e crescimento de plântulas de milho sob condições de déficit hídrico. Sci Agr. 11(2): 125-133.

Lee SH, Kim ES, Lee MY (2001) Purification and characterization of a cationic isoperoxidase from scentedgeranium. Phytochemistry. 58:859-864.

Lemos MSB, Machado Neto NB (1999) Avaliação do déficit hídrico na germinação de feijão (Phaseolus vulgaris L.). Colloquium, Presidente Prudente. 2: 21-26.

Lopes JC, Macêdo CMP (2008) Germinação de sementes de couve chinesa sob influência do teor de água, substrato e estresse salino. Rev Bras de Sementes. 30(3): 79-85.

Lopes NF, Lima MGS (2015) Fisiologia da produção. Viçosa: Ed. UFV. 492 p.

Machado Neto NB, Custódio CC, Maia CA, Matsumoto RS (2003) Estresse salino e hídrico durante a germinação em populações de feijoeiro comum (Phaseolus vulgaris L.). In: 
Congresso Brasileiro de Sementes, Informativo Abrates, 3: 71-78.

Marrou H, Vadez V, Sinclair TR (2015) Plant survival of drought during establishment: an interspecific comparison of five grain legumes. Crop Sci. 55: 1264-1273.

Matzenauer R, Maluf JRT, Barni NA, Radin B, Anjos CS (2004) Estimativa do consumo relativo de água para a cultura do feijoeiro na região do Planalto Médio do Rio Grande do Sul. Ciênc Rural. 34: 1363-1369.

Melo LC, Melo PGS, Faria LC, Diaz JLC, Del Peloso, Rava Ca, Costa JGC (2007) Interação com ambientes e estabilidade de genótipos de feijoeiro-comum na Região Centro-Sul do Brasil. Pesq AgropBras.42: 715-723.

Mittler R, Blumwald E (2010) Genetic engineering for modern agriculture: Challenges and perspectives. Annu Rev Plant Biol. 61:443-462.

Neto NMB, Custódio CC, Costa PR, Doná FL (2006) Deficiência hídrica induzida por diferentes agentes osmóticos na germinação e vigor de sementes de feijão. Rev Bras de Sementes. 28: 142-148.

Hsu SY, Kao CH. (2003) Differential effect of sorbitol andpolyethylene glycol on antioxidant enzymes in rice leaves. P Growth Regul. 39:83-89.

Jiang Y, Wu C, Zhang L, Hu P, Hou W, Zu W, Han T (2011) Long-day effects on the terminal inflorescence development of a photoperiod-sensitive soybean [Glycine $\max ($ L.) Merr.] variety. PI Sci. 180(1): 504-510.

Pedó T, Delias DS, Aisenberg GR, Szareski VJ, Carvalho IR, Nardino M, Souza VQ, Amarante L, Villela FA, Aumonde TZ (2016) Antioxidante enzyme activity and initial growth of wheat, rye and bean under soil flooding. Inter J Curr Res. 8(8): 36635 - 36642.
Peske ST, Villela FA, Meneguello Ge (2012) Sementes: fundamentos científicos e tecnológicos, 3: 573.

Ramalho MAP. Ferreira DF, Oliveira AC (2012) Experimentação em genética e melhoramento de plantas, 3: 305p.

Rossi C, Lima GPP, Hakvoort DMR (1997) Atividade de peroxidases (EC 1.11.1.7) e teor de prolina no embrião e cotilédones de feijoeiro Phaseolus vulgaris L. cultivado em condições de salinidade. Sci Agrícola. 54:123-127.

Shapiro SS, Wilk MB (1965) Analysis of Variance Test for Normality (Complete Samples). Biometrika ,52: 591-611.

Sousa MA, De Lima MDB (2010) Influência da supressão da irrigação em estádios de desenvolvimento do feijoeiro cv. Carioca comum. Biosc J. 26: 550-557.

Stülp M, Braccini AL, Albrecht LP, Ávila MR, Scapim CA, Schuster I (2009) Desempenho agronômico de três cultivares de soja em diferentes épocas de semeadura em duas safras. Ciênc e Agrotec. 33(1): 1240-1248.

Silva VR, Reichert JM, Reinert DJ (2006) Variação na temperatura do solo em três sistemas de manejo na cultura do feijão. R Bras Ciênc Solo. 30: 391-399.

Szareski VJ, Zanatta E, Koch, F, Aisenberg GR, Demari GH, Kehl K, Pimentel JR, Carvalho IR, Nardino M, Trombeta HW, Souza VQ, Martinazzo EG, Pedo T, Aumonde TZ (2016) Pre-harvest desiccation and seed production in soybean crops. Inter Curr Res. 8(11): 41534 - 41537.

Troyjack C, Dubal I, Koch F, Szareski VJ, Pimentel JR, Carvalho IR, Nardino M, Demari GH, Lautenchleger F, Souza VQ, Villela FA, Aumonde TZ, Pedo T (2017) Attributes of growth, physiological quality and isoenzymatic expression of common bean seeds produced under the effect of gibberellic acid Aust J Crop Sci. 11(9): 1116-1122. 